\title{
PENENTUAN DOSIS DAN UKURAN BUTIR PUPUK FOSFAT SUPER TERBAIK UNTUK MENDUKUNG PERTUMBUHAN DAN SERAPAN $P$ TANAMAN KEDELAI (Glycine $\max [$ L.] Merril)
}

\author{
Aulia Rosi, Ainin Niswati, Sri Yusnaini \& Abdul Kadir Salam \\ Jurusan Agroteknologi Fakultas Pertanian Universitas Lampung \\ Jl. Prof. Dr. Soemantri Brodjonegoro No. 1 Bandar Lampung 35141 \\ Email:Rosiaulia14@yahoo.com
}

\begin{abstract}
ABSTRAK
Pemupukan merupakan cara yang dilakukan dalam pemberian unsur hara ke tanah sesuai yang dibutuhkan tanaman. Salah satu unsur hara makro yang dibutuhkan tanaman yaitu fosfor. Umumnya fosfor ditambahkan dari pupuk fosfat industri dengan harga yang semakin meningkat sehingga dicari pupuk yang berasal dari batuan fosfat yang ditambah limbah cair tahu dan asam sulfat untuk meningkatkan kelarutan fosfor. Pupuk tersebut dinamakan Fosfat super, merupakan hasil asidulasi batuan fosfat dengan kombinasi antara $85 \%$ limbah cair tahu dan $15 \% \mathrm{H}_{2} \mathrm{SO}_{4} 1 \mathrm{~N}$ Pupuk Fosfatsuper akan diuji kelarutannya dalam menyediakan unsur hara bagi tanaman kedelai. Penelitian ini bertujuan untuk menentukan dosis dan ukuran butir pupuk Fosfatsuper yang tepat dalam pertumbuhan dan serapan P tanaman kedelai. Penelitian dilaksanakan di rumah kaca Ilmu Tanah, Laboratorium Teknologi Pertanian dan Laboratorium Ilmu Tanah Fakultas Pertanian Universitas Lampung dari bulan September 2014 sampai dengan April 2015. Penelitian disusun secara faktorial 2x4 dalam Rancangan Acak Kelompok (RAK) dengan 3 ulangan. Faktor pertama adalah dosis pupuk Fosfatsuper $\left(360 \mathrm{~kg} \mathrm{ha}^{-1} ; 720 \mathrm{~kg} \mathrm{ha}^{-1}\right)$ dan faktor kedua adalah ukuran butir pupuk Fosfatsuper ( $1 \mathrm{~mm} ; 2-3 \mathrm{~mm} ; 3-4 \mathrm{~mm} ;>5 \mathrm{~mm}$ ). Hasil penelitian menunjukkan bahwa dosis dan ukuran butir pupuk Fosfatsuper tidak mempengaruhi tinggi tanaman, jumlah daun, bobot akar kering, bobot tajuk kering, P-tersedia, serapan P, dan pH tanah fase vegetatif akhir. Namun demekian, uji korelasi menunjukkan korelasi nyata positif terjadi antara serapan unsur hara $\mathrm{P}$ dengan jumlah daun, bobot akar kering, dan bobot tajuk kering tanaman kedelai.
\end{abstract}

Kata kunci: asam sulfat, dosis pupuk, fosfatsuper, kedelai, ukuran butir.

\section{PENDAHULUAN}

Indonesia merupakan negara agraris yang sebagian besar penduduknya bekerja di bidang pertanian. Sektor pertanian di Indonesia berperan penting dalam pembangunan perekonomian nasional, sehingga menyebabkan kebutuhan pupuk terus meningkat. Pupuk merupakan salah satu faktor penting dalam budidaya pertanian, yaitu pertumbuhan tanaman. Salah satu faktor pertumbuhan untuk menjaga produksi optimum tanaman yaitu ketersediaan hara di dalam tanah seperti fosfor. Pupuk P umumnya dibuat dari batuan fosfat alam melalui proses industri, meskipun batuan fosfat dapat diaplikasikan langsung ke tanah tetapi lambat tersedia (Suciati, 2004). Selain itu tidak adanya subsidi pupuk menyebabkan harga pupuk meningkat (Pramono, 2000). Oleh karena itu perlu dicari alternatif lain untuk mengatasinya, yaitu penggunaan pupuk Fosfatsuper.

Pupuk alternatif Fosfatsuper merupakan hasil asidulasi batuan fosfat, $85 \%$ limbar cair tahu, dan $15 \%$ $\mathrm{H}_{2} \mathrm{SO}_{4} 1 N$ (Aini, 2013). Hasil penelitian Aini (2013) menunjukkan kelarutan P-total batuan fosfat yang diasidulasi dengan $85 \%$ limbah cair tahu dan $15 \% \mathrm{H}_{2} \mathrm{SO}_{4}$ $1 \mathrm{~N}$ adalah $10,80 \%$. Berdasarkan kelarutan $\mathrm{P}$ yang tinggi maka pupuk Fosfatsuper akan diuji kelarutannya alam menyediakan unsur hara pada tanaman kedelai. Hal ini karena kedelai merupakan tanaman pangan ketiga setelah padi dan jagung, sehingga kebutuhan kedelai terus meningkat. Rendahnya hasil kedelai terutama disebabkan oleh pemupukan yang belum memadai serta kondisi lahan yang masam. Kedelai memerlukan unsur hara yang cukup banyak dan berimbang. Apabila dosis dan ukuran butir yang digunakan dalam pemupukan tepat diharapkan dapat mengoptimalkan pertumbuhan, dan serapan $\mathrm{P}$ pada tanaman.

Penelitian ini bertujuan untuk menentukan dosis pupuk Fosfatsuper terbaik terhadap pertumbuhan dan serapan P tanaman kedelai; menentukan ukuran butir pupuk Fosfatsuper terbaik terhadap pertumbuhan, dan serapan P tanaman kedelai; mengetahui interaksi antara dosis dan ukuran butir pupuk Fosfatsuper terhadap pertumbuhan, dan serapan $\mathrm{P}$ tanaman kedelai, serta mengetahui korelasi antara sifat kimia tanah dengan komponen pertumbuhan tanaman kedelai. 


\section{BAHAN DAN METODE}

Penelitian ini disusun secara faktorial $2 \times 4$ dalam Rancangan Acak Kelompok (RAK) dengan 3 kelompok. Faktor pertama adalah dosis pupuk fosfat super $(\mathrm{P})$ yaitu $\mathrm{P}_{1}=360 \mathrm{~kg} \mathrm{ha}^{-1}$ atau setara dengan pupuk SP-36 dosis $100 \mathrm{~kg} \mathrm{ha}^{-1 ;} \mathrm{P}_{2}=720 \mathrm{~kg} \mathrm{ha}^{-1}$ atau setara dengan pupuk SP-36 dosis $200 \mathrm{~kg} \mathrm{ha}^{-1}$. Faktor kedua adalah ukuran butir pupuk fosfat super $(\mathrm{T})$ yaitu $\mathrm{T}_{1}=1 \mathrm{~mm} ; \mathrm{T}_{2}=2-3$ $\mathrm{mm} ; \mathrm{T}_{3}=3-5 \mathrm{~mm}$; dan $\mathrm{T}_{4}>5 \mathrm{~mm}$. Homogenitas ragam antar perlakuan diuji dengan uji Bartlett dan aditivitas data diuji dengan uji Tukey. Jika asumsi terpenuhi, data dianalisis ragam dan dilanjutkan dengan uji BNT taraf 5\%. Uji korelasi dilakukan antara sifat kimia tanah dengan komponen pertumbuhan tanaman kedelai.

Pembuatan Pupuk Fosfat Super yaitu limbah cair tahu disiapkan dalam keadaan segar dan pelarut asam sulfat $\left(\mathrm{H}_{2} \mathrm{SO}_{4} 1 \mathrm{~N}\right)$. Tepung fosfat (lolos saringan 1 $\mathrm{mm}$ ) ditimbang $0,5 \mathrm{~kg}$. Kemudian sebanyak 0,5 tepung batuan fosfat, $425 \mathrm{ml}$ limbah cair tahu, dan $75 \mathrm{ml}\left(\mathrm{H}_{2} \mathrm{SO}_{4}\right.$ $1 \mathrm{~N}$ ) secara bersamaan dan perlahan-lahan dimasukkan ke dalam mixer selama 5 menit. Setelah itu campuran tersebut dituang ke dalam toples dan di masukkaan dalam kontener $1 \mathrm{~m}$ x $1 \mathrm{~m}$ x 0,5 m selama seminggu.

Pupuk Fosfat super dibuat granul menggunakan alat granulator di Laboratorium Teknologi Pertanian Universitas Lampung. Hasil granulasi kemudian diambil dan dikeringkan dengan cara penjemuran langsung oleh sinar matahari. Pupuk yang sudah kering dianalisis distribusi diameter granul dengan menggunakan ayakan
(1 mm, 2-3 mm, 3-5 mm, dan >5 mm). Tahapan persiapan media tanam dan pemupukan yaitu tanah diambil dari kebun percobaan Fakultas Pertanian Unila di Desa Tanjung Sari Kecamatan Natar. Tanah digali sampai kedalaman $20 \mathrm{~cm}$, dibersihkan dari bebatuan dan akar, kemudian dikeringanginkan, diayak, dan dikompositkan. Tanah ditimbang seberat $5 \mathrm{~kg}$ Berat Kering Oven (BKO) dan dimasukkan dalam polibag. Pemberian pupuk dilakukan satu minggu setelah tanam (MST) dengan aplikasi urea dosis $0,6 \mathrm{~g} 5 \mathrm{~kg}$ tanah $^{-1}$, Fosfatsuper dosis $2,88 \mathrm{~g} 5 \mathrm{~kg}^{-t_{a n a h}{ }^{-1}}$ dan $5,76 \mathrm{~g} 5 \mathrm{~kg}$ tanah $^{-1}$ serta aplikasi $\mathrm{KCl}$ dosis $1,6 \mathrm{~g} 5 \mathrm{~kg}$ tanah $^{-1}$.

\section{HASIL DAN PEMBAHASAN}

Pengamatan tinggi tanaman kedelai dilakukan setiap minggu sampai fase vegetatif akhir tanaman yaitu 5 minggu setelah tanam (5 MST). Perbandingan antar perlakuan dapat dilihat pada Gambar 1A. Hasil analisis ragam menunjukkan bahwa dosis dan ukuran butir pupuk Fosfatsuper tidak berpengaruh nyata terhadap tinggi tanaman kedelai. Hal ini disebabkan oleh unsur hara fosfor yang bersifat immobil dan diserap dalam bentuk senyawa anorganik, sehingga tidak cepat tersedia di dalam tanah dan diserap oleh tanaman. Dugaan lain karena terjadinya fiksasi fosfor yang menyebabkan $\mathrm{P}$ di dalam tanah akan berkurang dikarenakan hara besi, aluminium, dan mangan dapat larut dalam tanah mineral sangat masam, dan terjadi reaksi ion $\mathrm{H}_{2} \mathrm{PO}_{4}$ yang mengubah fosfor menjadi tidak larut dan juga tidak
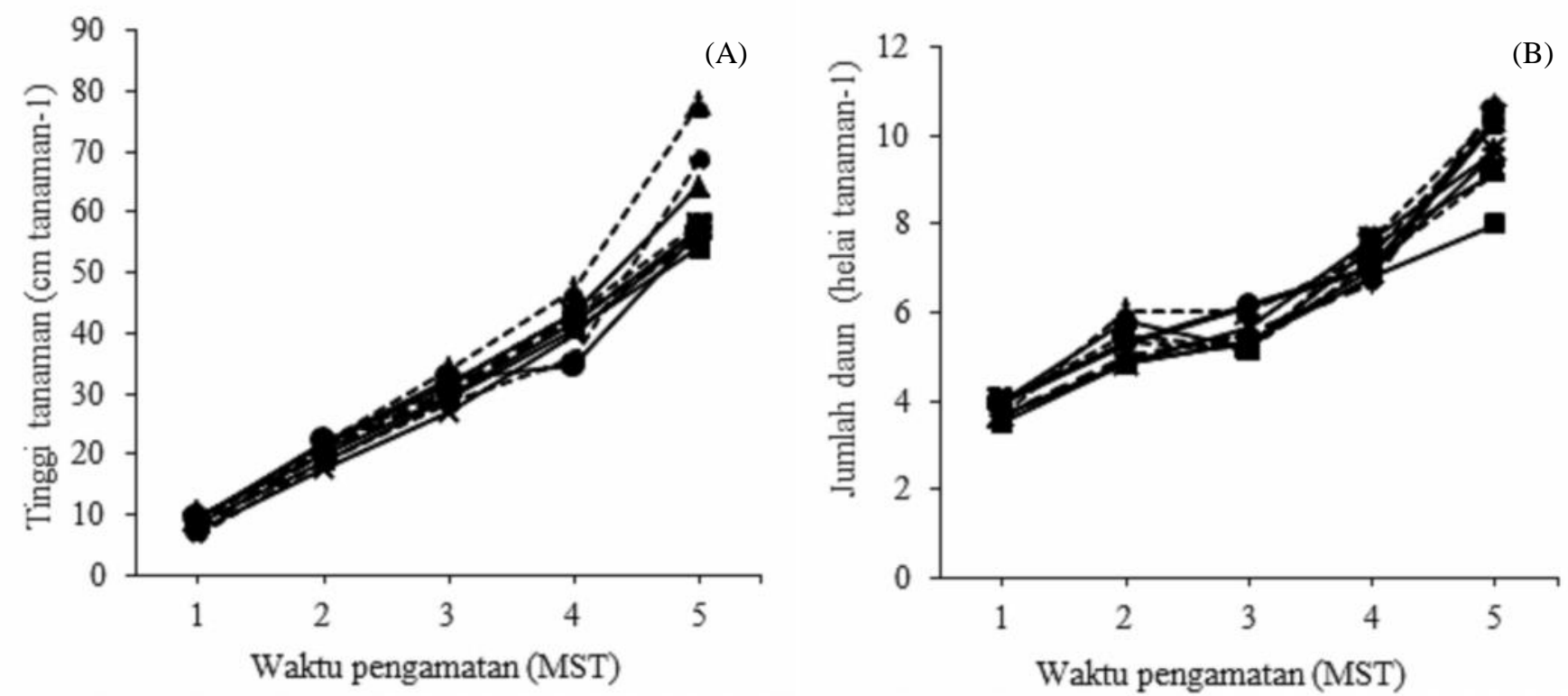

Gambar 1. Tinggi tanaman (A) dan jumlah daun (B) pada kedelai sampai dengan fase vegetatif akhir (5MST) pada

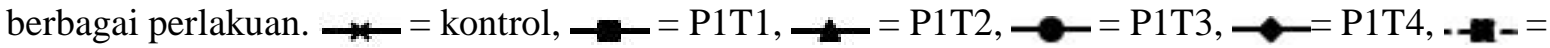

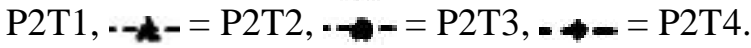


tersedia bagi pertumbuhan tanaman. Pengamatan jumlah daun tanaman kedelai dilakukan setiap minggu sampai fase vegetatif akhir tanaman yaitu 5 minggu setelah tanam (Gambar 1B). Hasil analisis ragam menunjukkan bahwa dosis dan ukuran butir pupuk Fosfatsuper tidak berpengaruh nyata terhadap jumlah daun tanaman kedelai. Hal ini disebabkan oleh unsur $\mathrm{P}$ tidak tersedia sehingga lambat diserap akar tanaman. Menurut Buckman dan Brady (1982) bahwa kandungan P di dalam larutan tanah yaitu $<1 \mathrm{ppm}$ sehingga menyebabkan persaingan antar koloid tanah dengan tanaman dan berpengaruh terhadap nutrisi akar tanaman. Hal ini sesuai dengan penelitian Rukmi (2009) pemupukan fosfat tidak berpengaruh nyata terhadap tinggi tanaman, dan jumlah daun pada tanaman. Berdasarkan pengamatan, bahwa kecepatan perubahan jumlah daun mengalami peningkatan hingga fase vegetatif akhir.

Berdasarkan analisis ragam bahwa dosis dan ukuran butir pupuk Fosfatsuper tidak berpengaruh terhadap bobot akar dan bobot tajuk kering tanaman kedelai. Lakitan (2012) mengatakan bahwa banyaknya nutrisi yang dikandung tanaman berasal dari bobot kering tanaman dan tergantung dari laju respirasi fotosintesis serta unsur hara yang diserap tanaman. Hasil pengamatan nilai rata-rata bobot akar kering perlakuan $\mathrm{P}_{2} \mathrm{~T}_{2}$ (dosis rekomendasi $720 \mathrm{~kg} \mathrm{ha}^{-1}$ dan ukuran butir 2-3 $\mathrm{mm}$ ) lebih tinggi dibanding dengan perlakuan lainnya. Hal ini disebabkan oleh fosfor yang diserap tanaman dalam bentuk ion anorganik cepat berubah menjadi senyawa organik. Perbandingan bobot akar dan tajuk kering tanaman kedelai antar perlakuan dapat dilihat pada Gambar 2A.

Tisdale dkk. (1985) menyatakan bahwa semakin banyak perakaran tanaman, maka semakin luas akar tanaman menyerap unsur hara Kadar optimum fosfor tanaman pada saat pertumbuhan vegetatif yaitu $0,3-$ $0,5 \%$ dari bobot kering tajuk tanaman. Apabila bobot tajuk kering tanaman rendah maka pertumbuhan vegetatif tanaman akan terhambat, karena hara yang diserap sedikit sehingga mempengaruhi pertumbuhan tanaman.

Perbandingan P-tersedia tanah pasca panen dapat dilihat pada Gambar 2B. Berdasarkan Gambar tersebut terlihat bahwa $\mathrm{P}$-tersedia pada perlakuan $\mathrm{P}_{2} \mathrm{~T}_{1}$ (dosis $720 \mathrm{~kg} \mathrm{ha}^{-1}$ dan ukuran butir $1 \mathrm{~mm}$ ) lebih rendah dibandingkan dengan analisis awal dan perlakuan lainnya. Hal ini diduga karena dosis yang tinggi dengan ukuran butir yang halus menyebabkan pupuk Fosfatsuper cepat larut dan mengalami pengendapan sehingga tidak tersedia bagi tanaman. Kandungan P-tersedia analisis tanah awal yaitu 5,78 ppm dan kandungan P-larut pada pupuk Fosfatsuper sebesar $10,80 \% \mathrm{P}_{2} \mathrm{O}_{5}$. Artinya kandungan pupuk Fosfatsuper yang diberikan pada tanaman kedelai memiliki P-larut yang tinggi. Kandungan $\mathrm{pH}$ tanah $<6$ menyebabkan $\mathrm{Al}$ dan $\mathrm{Fe}$ meningkat, sehingga terjadinya fiksasi fosfor di dalam tanah. Koloid Al dan Fe cepat terbentuk dan akan
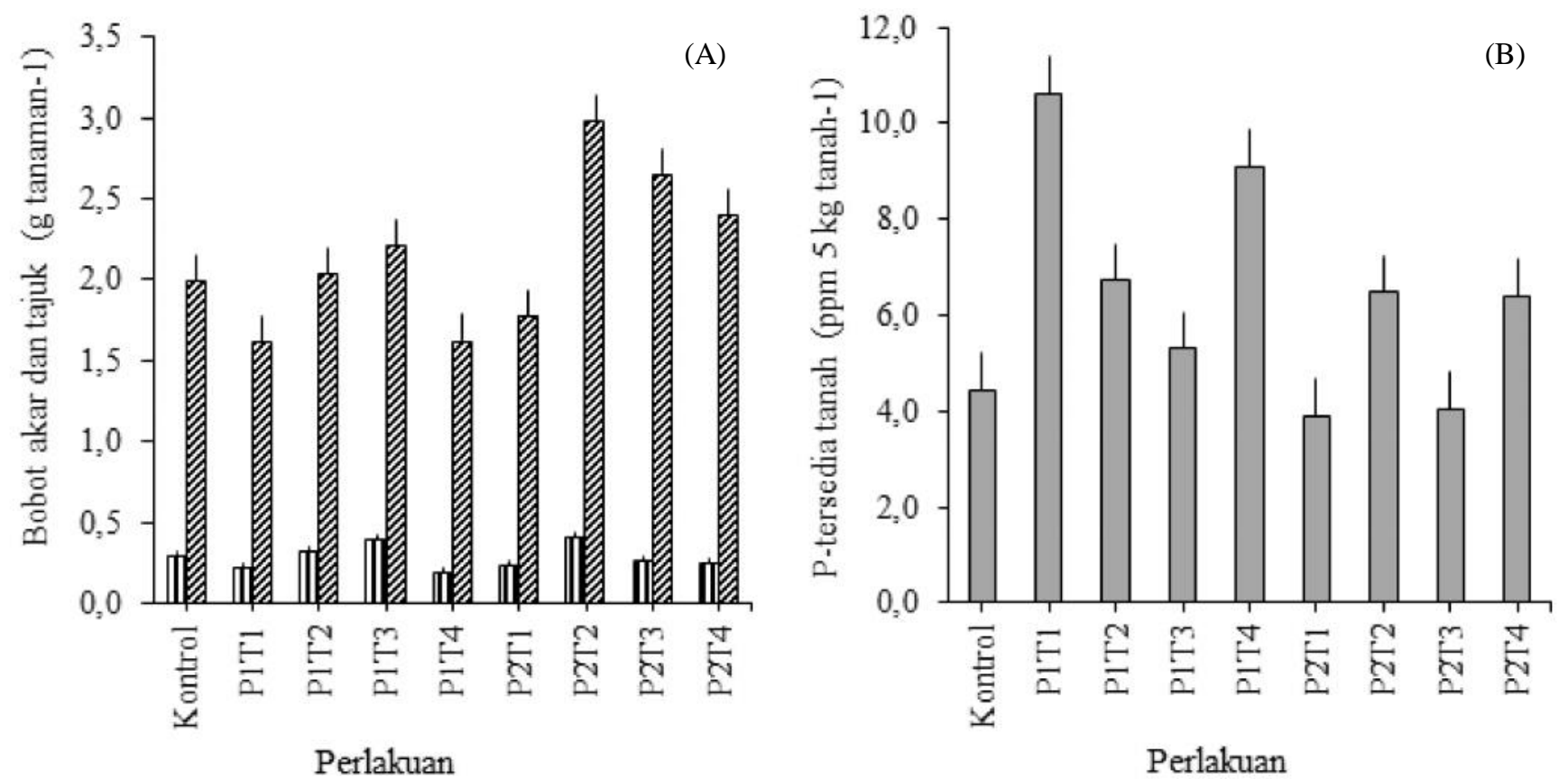

Gambar 2. (A) Bobot akar kering (BAK) dan bobot tajuk kering (BTK) serta (B) P-tersedia tanah pada fase vegetatif akhir tanaman kedelai pada berbagai perlakuan. $\mathbf{D}=\mathrm{BAK}, \boldsymbol{\nabla}=\mathrm{BTK}, \boldsymbol{\square}=\mathrm{P}$-tersedia. 
mengikat fosfor sehingga tidak tersedia di dalam tanah dan sulit diserap tanaman. Adapun faktor-faktor yang dapat mempengaruhi ketersediaan $\mathrm{P}$ dalam tanah antara lain tipe liat, reaksi tanah, waktu reaksi, temperatur, dan bahan organik tanah (Foth, 1994).

Perbandingan serapan $\mathrm{P}$ tanaman kedelai dapat dilihat pada Gambar 3A. Berdasarkan analisis ragam menunjukkan bahwa perlakuan dosis dan ukuran butir pupuk Fosfatsuper tidak berpengaruh nyata pada serapan $\mathrm{P}$ tanaman kedelai. Faktor yang mempengaruhi penyerapan unsur hara $\mathrm{P}$ yaitu faktor air yang berfungsi untuk melarutkan unsur hara atau zat mineral sehingga mudah menyerap unsur hara. Daya serap akar juga dapat meningkatkan serapan hara P bagi tanaman. Serapan $\mathrm{P}$ berhubungan dengan konsentrasi $\mathrm{P}$ di dalam larutan tanah, dan dipengaruhi oleh $\mathrm{pH}$ tanah. Penyerapan anion akan berkurang dan meningkatkan kepekaan $\mathrm{OH}^{-}$sehingga $\mathrm{pH}<6,00$ kurang dapat dikendalikan.

Analisis ragam bahwa dosis dan ukuran butir pupuk Fosfatsuper tidak berpengaruh nyata terhadap $\mathrm{pH}$ tanah. Berdasarkan analisis tanah awal Tabel 1 bahwa kandungan $\mathrm{pH}$ tanah sebesar 6,71 dan $\mathrm{pH}$ pupuk Fosfatsuper sebesar 7,95. Setelah dilakukan aplikasi perlakuan pupuk Fosfatsuper kandungan $\mathrm{pH}$ antara $5,49-5,88$. Penurunan $\mathrm{pH}$ disebabkan oleh penurunan basa $\left(\mathrm{OH}^{-}\right)$di dalam tanah dan terjadi reaksi antara pupuk Fosfatsuper dengan koloid tanah. Jika dosis yang diberikan tinggi, maka semakin banyak konsentrasi ion $\mathrm{H}^{+}$dan terjadi penurunan ion $\mathrm{OH}^{-}$sehingga menurunkan $\mathrm{pH}$ tanah. Perubahan $\mathrm{pH}$ tersebut sangat mempengaruhi

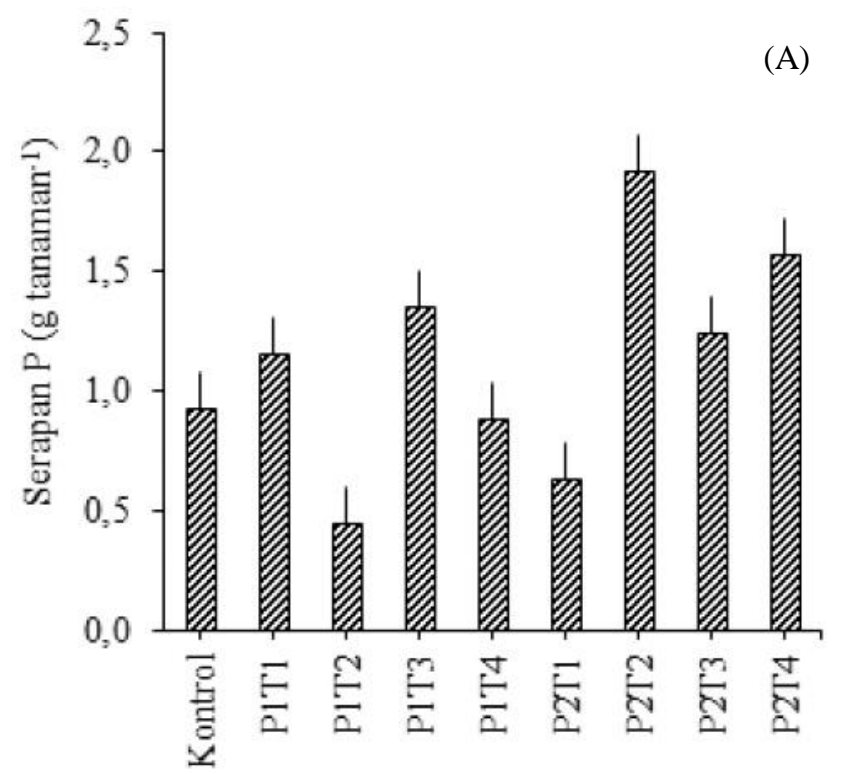

Perlakuan pertumbuhan tanaman kedelai. Menurut Purwono dan Heni (2012) tanaman kedelai dapat tumbuh pada keasaman $\mathrm{pH}$ antara 5,0-7,0. Selain itu kondisi tanah yang tidak sesuai akan menyebabkan pertumbuhan terhambat karena akar tidak dapat menyerap hara sesuai yang dibutuhkan dan dapat menjadi salah satu faktor pembatas terhadap pertumbuhan tanaman kedelai. Perbandingan $\mathrm{pH}$ tanah dapat dilihat pada Gambar 3B.

Hasil uji korelasi Tabel 2 menunjukkan terjadi korelasi positif nyata antara serapan $\mathrm{P}$ dengan jumlah daun, bobot akar kering, dan bobot tajuk kering. Artinya semakin tinggi serapan hara P maka jumlah daun, bobot akar kering, dan bobot tajuk kedelai semakin meningkat. Hal ini disebabkan karena serapan hara P dapat diserap oleh akar dan ditranslokasikan ke tanaman sehingga bobot keringnya dapat meningkat.

Peningkatan jumlah daun, bobot akar kering, dan bobot tajuk kering tanaman disebabkan oleh peningkatan serapan hara $\mathrm{P}$ oleh tanaman kedelai. Hal ini disebabkan oleh pupuk Fosfatsuper memiliki kandungan sebesar $10,80 \% \mathrm{P}_{2} \mathrm{O}_{5}$, kelarutan yang tersebut dapat menyediakan P-tersedia di dalam tanah dan dapat diserap oleh tanaman. Noor (2005) menyatakan peningkatan serapan $\mathrm{P}$ disebabkan meningkatnya sifat kimia tanah seperti P-tersedia didalam tanah. Berdasarkan penelitian Sari (2014) pemberian pupuk Fosfatsuper 360-720 $\mathrm{kg} \mathrm{ha}^{-1}$ dapat meningkatkan Ptersedia sebesar 8,02 ppm pada tanaman jagung dibandingkan dengan kontrol. Saat tanaman membentuk perakaran dan dapat menyerap hara $\mathrm{P}$ yang tersedia di dalam tanah dan ditranslokasikan keseluruh bagian atas

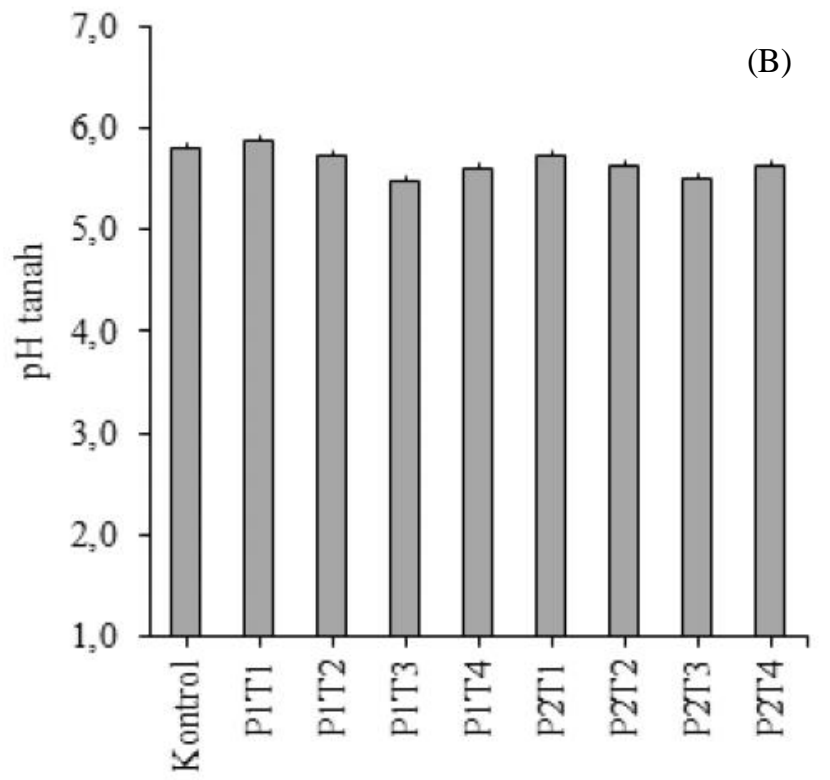

Perlakuan

Gambar 3. Serapan P (A) dan pH tanah pada fase vegetatif akhir tanaman kedelai pada berbagai perlakuan. 
Tabel 1. Hasil analisis awal sifat tanah dan pupuk.

\begin{tabular}{clccc}
\hline \multirow{2}{*}{ No } & \multirow{2}{*}{ Parameter } & \multirow{2}{*}{ Satuan } & \multicolumn{2}{c}{ Hasil analisis } \\
\cline { 4 - 5 } & & & Tanah & Pupuk \\
\hline 1 & $\mathrm{pH} \mathrm{H}_{2} \mathrm{O}$ & - & 6,71 & 7,95 \\
2 & P-tersedia & ppm & 5,78 & - \\
3 & P-larut & $\%$ & - & 10,8 \\
\hline
\end{tabular}

Tabel 2. Korelasi antara sifat kimia tanah dengan komponen pertumbuhan terhadap tanaman kedelai.

\begin{tabular}{lcccc}
\hline \multirow{2}{*}{ Variabel } & \multicolumn{4}{c}{ Koefisisen korelasi (r) } \\
\cline { 2 - 5 } & TT & JD & BAK & BTK \\
\hline pH tanah & $-0,33^{\text {tn }}$ & $-0,33^{\text {tn }}$ & $-0,33^{\text {tn }}$ & $-0,39^{\text {tn }}$ \\
Serapan P & $0,31^{\text {tn }}$ & $0,53^{*}$ & $0,43^{*}$ & $0,73^{*}$ \\
P-tersedia & $0,20^{\text {tn }}$ & $0,11^{\text {tn }}$ & $0,12^{\text {tn }}$ & $0,19^{\text {tn }}$ \\
\hline
\end{tabular}

Keterangan: $\mathrm{TT}=$ tinggi tanaman, $\mathrm{JD}=$ jumlah daun, BAK = bobot akar kering, BTK = bobot tajuk kering. $*=$ berkorelasi nyata pada taraf $5 \% \mathrm{tn}=$ tidak berkorelasi nyata pada taraf $5 \%$.

tanaman. Hal tersebut terjadi melalui mekanisme aliran massa, diffusi, dan intersepsi akar.

\section{KESIMPULAN}

Pada pengujian diperoleh bahwa pupuk Fosfatsuper baik dosis maupun ukuran butir tidak berpengaruh nyata terhadap pertumbuhan dan serapan P tanaman kedelai. Tidak terdapat interaksi antara dosis dan ukuran butir pupuk Fosfatsuper terhadap pertumbuhan dan serapan $\mathrm{P}$ tanaman kedelai. Terdapat korelasi yang nyata dan positif antara serapan hara $\mathrm{P}$ dengan jumlah daun, bobot kering akar, dan bobot kering tajuk, namun tidak berkorelasi terhadap tinggi tanaman kedelai.

\section{DAFTAR PUSTAKA}

Aini, S. N. 2013. Pengaruh Perbandingan Campuran Limbah Cair Tahu dengan Asam Sulfat serta Lama Inkubasi dalam Proses Asidulasi Batuan Fosfat terhadap Fosfat Larut. Skripsi. Universitas Lampung. Bandarlampung. $52 \mathrm{hlm}$.

Buckman, H.O dan L.D, Brady., 1984. Ilmu Tanah. Terjemahan Soegiman. Braharta Aksara. Jakarta. $788 \mathrm{hlm}$.
Foth. D. H. 1994. Dasar-dasar Ilmu Tanah. Gelora Aksara Pratama. Jakarta. 373 hlm.

Hakim. N, M. Y. Nyapka, A. M. Lubis, S. G. Nugroho, M. R. Saul, M. A. Diha, B. H. Go, N. H. Bailey. 1986. Dasar-dasar Ilmu Tanah. Penerbit Universitas Lampung. Bandar lampung. $488 \mathrm{hlm}$.

Istigani, M., S. Kabirun, dan SA Siradz. 2005. Pengaruh inokulasi bakteri pelarut fosfat terhadap pertumbuhan sorghum pada berbagai kandungan P tanah. J. Ilmu Tanah dan Lingkungan. 5: 4854.

Lakitan, B. 2012. Dasar-dasar Fisiologi Tumbuhan. PT Raja Grafindo Persada. Jakarta. 205 hlm.

Niswati A., S. Yusnaini, dan Sarno. 2014. The potency of agroindustrial wastewaters for increasing soluble-P from phosphate rock . J.Trop.Soils 19(1): 2 .

Noor. A. 2005. Peranan fosfat alam dan kombinasi bakteri pelarut fosfat dengan pupuk kandang dalam meningkatkan serapan hara dan hasil kedelai. J.Tanah dan Lingkungan. 7(2): 41-47.

Pramono, J. 2000. Pengaruh fosfat alam dan bahan organik terhadap kelarutan pupuk ciri kimia tanah dan efisiensi pemupukan P pada Typic Hapludox Sitiung Sumbar. Tesis. Program Pasca Sarjana, IPB.

Purwono dan Heni, P. 2011. Budidaya 8 Jenis Tanaman Pangan Unggul. Penebar Swadaya. Jakarta. $139 \mathrm{hlm}$.

Rukmi. 2009. Pengaruh Pemupukan Kalium dan Fosfat terhadap Pertumbuhan dan Hasil Kedelai. Karya Ilmiah Fakultas Pertanian. Universitas Muria Kudus. Hal 1-13.

Sari, D. N. 2014. Pengaruh Ukuran Butir dan Dosis Pupuk Fosfatsuper yang Diasidulasi Limbah Cair Tahu terhadap Serapan P dan Pertumbuhan Tanaman Jagung (Zea Mays L.). Seminar hasil penelitian. $17 \mathrm{hlm}$.

Suciati, R. 2004. Penggunan pupuk fosfat plus Zn berdasarkan SNI. J. Standarisasi. 6(2). 2 Juli 2004. Badan Standarisasi Nasional.

Suriadikarta, D. A., dan I P.G. Widjaja-Adhi. 1986. Pengaruh residu pupuk fosfat, kapur, dan bahan organik terhadap kesuburan tanah dan hasil kedelai pada Inseptisols Rangkasbitung. Pemb. Pen. Tanah dan Pupuk 6: 15-19. 